Dhaka Univ. J. Biol. Sci. 23(2): 127-133, 2014 (July)

\title{
ANTHRACNOSE OF BETEL VINE AND ITS IN VITRO MANAGEMENT
}

\author{
MD. JunAyed Ahmed, K.S. Hossain ${ }^{1}$ And M.A. BASHAR* \\ Department of Botany, University of Dhaka, Dhaka-1000, Bangladesh
}

Key words: Anthracnose, Betel vine, In vitro management

\begin{abstract}
The incidence of anthracnose disease was observed lowest in December $(10.87 \%)$ and highest in July $(80.50 \%)$ at the three selected betel vine fields of Shalon village in Moulvibazar district. The young stems were found more prone to attack than the old ones. Pathogenicity test showed Colletotrichum dematium and C. gloeosporioides produced characteristic disease symptoms on betel stems. Among them $C$. dematium is a new document as a pathogen of anthracnose of betel vine. Out of five fungicides, complete inhibition of both the pathogens in vitro occurred with corozole EC (25\% propiconazole), folicur EC (25\% tebuconazole) and trooper WP (75\% tricyclazole). Among the four antagonistic fungi, Penicillium sp. showed more antagonistic potentiality against the pathogens.
\end{abstract}

\section{Introduction}

Betel vine (Piper betle L.), a cash crop in Bangladesh, covers about 14,175 ha of land producing about 72,500 tons of leaves annually ${ }^{(1)}$. Its leaf, as a masticatory, is credited with being aromatic, digestive, carminative and stimulant. The volatile oil of leaves has been found to be antiseptic and is used in treatment of bronchitis, cough, cold and chills $\mathbf{s}^{(2,3)}$.

The crop suffers from a number of fungal diseases, among them anthracnose is one which reduces its productivity considerably and limit commercial cultivation of the crop $^{(4)}$. The disease affects both leaf and stem of the plant. Colletotrichum capsici (Syd. \& P. Syd.) Butler \& Bisby (5,6), C. gloeosporioides Penz.(5) and C. piperis Petch ${ }^{(7)}$ were reported as the causal agents of anthracnose disease of betel vine.

Nowadays, many inorganic and organic fungicides are used frequently to control plant diseases ${ }^{(8)}$. Various workers in different countries evaluated the efficacy of various fungicides against Colletotrichum spp. under laboratory and field conditions ${ }^{(9-11)}$. All these fungicides are not available in Bangladesh. Moreover, some isolates of C. gloeosporioides exhibit resistant to fungicides ${ }^{(12)}$. Therefore, it is necessary to test the efficacy of the fungicides against the pathogens.

Study of antagonist as biological control agent has now become one of the most exciting and rapidly developing areas in plant pathology because it has great potential to solve many agricultural and environmental problems. A number of researchers have

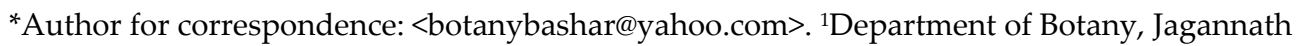
University, Dhaka-1100, Bangladesh.<ksh1968@gmail.com> 
studied colony interaction between non-pathogenic and pathogenic fungi for determination of antagonism of fungi isolated from different habitats ${ }^{(13,14)}$.

Occurrence of anthracnose of betel vine was reported for the first time by Hasan and Ahmed(15) from Bangladesh. Recent information on the diseases of betel vine in Bangladesh appears to be limited(6). Keeping all these views in mind, the present work was carried out to investigate the incidence of disease and its in vitro management of anthracnose pathogen(s) by using fungicides and antagonists.

\section{Materials and Methods}

Several field visits were made during December, 2009 to July, 2010 at Shalon village of Kulaura Upazilla in Moulvibazar district. Three betel vine fields were selected randomly. The per cent disease incidence (DI) was calculated by adopting the formula stated by Hossain et al.(16).

Anthracnose infected stems of betel vine were collected in the sterile polyethylene bag. Fungi associated with anthracnose infected stem were isolated following standard agar plate method. Fungi growing out of the inocula were identified in situ whenever possible, purified and maintained on PDA slants. Per cent frequency of the fungal isolates was calculated by adopting the formula of Spurr and Welty ${ }^{(17)}$. Identities of the isolates were determined following the standard literatures ${ }^{(18,19)}$.

On the basis of higher per cent frequency and previous report as a causal agent of anthracnose disease of betel vine or other crops Colletotrichum gloeosporioides Penz. and C. dematium (Pers. Ex Fr.) grove were selected and their pathogenicity were tested following Kochs postulates into a shady net house at Carzon Hall campus of Dhaka University.

In vitro fungitoxicity of five systemic fungicides viz., bavistin WP (50\% carbendazim), corozole EC ( $25 \%$ propiconazole), folicur EC (25\% tebuconazole), fuji-one EC ( $40 \%$ isoprothiolane) and trooper WP (75\% tricyclazole) at 50, 100, 200, 300, 400 and 500 ppm concentrations were evaluated against Colletotrichum dematium and C. gloeosporioides following poisoned food technique with three replications. The radial growth of the colonies were measured at the seventh day of incubation. The per cent growth inhibition of each test pathogen was calculated following the formula of Hossain and Bashar ${ }^{(20)}$. The results were statistically analyzed by "t" test following Steel and Torrie(21).

Some soil fungi were isolated from garden soil following serial dilution method. Their identities were determined following the standard literatures $(18,22,23)$. From the identified soil fungi, Aspergillus flavus Link., A. niger Tiegh., Penicillium sp. and Trichoderma viride Pers. were selected randomly to study its antagonistic potentiality against the test pathogens following Skidmore and Dickinson ${ }^{(13)}$. The parameters used for the assessment of colony interactions were the width of inhibition zone, intermingled zone and per cent inhibition of radial growth of the pathogen. 


\section{Results and Discussion}

Disease intensity of anthracnose of betel vine in three selected fields at Shalon village is shown in Fig. 1. The results indicated that the anthracnose disease was found in every visit at every field during the survey period. Characteristic brown or deep brown lesions appeared on the inter-nodal portion of betel stem. The sizes of the lesions were measured about $15 \times 3-28 \times 5.5 \mathrm{~mm}^{2}$. The young stems were more prone to attack than the old ones. In contrast with the present study, Shahzad(5) reported that anthracnose of betel vine caused chiefly by $C$. capcisi was found severe in old plantation as compared to young one. This disparity might be due to the variation in the causal organisms.

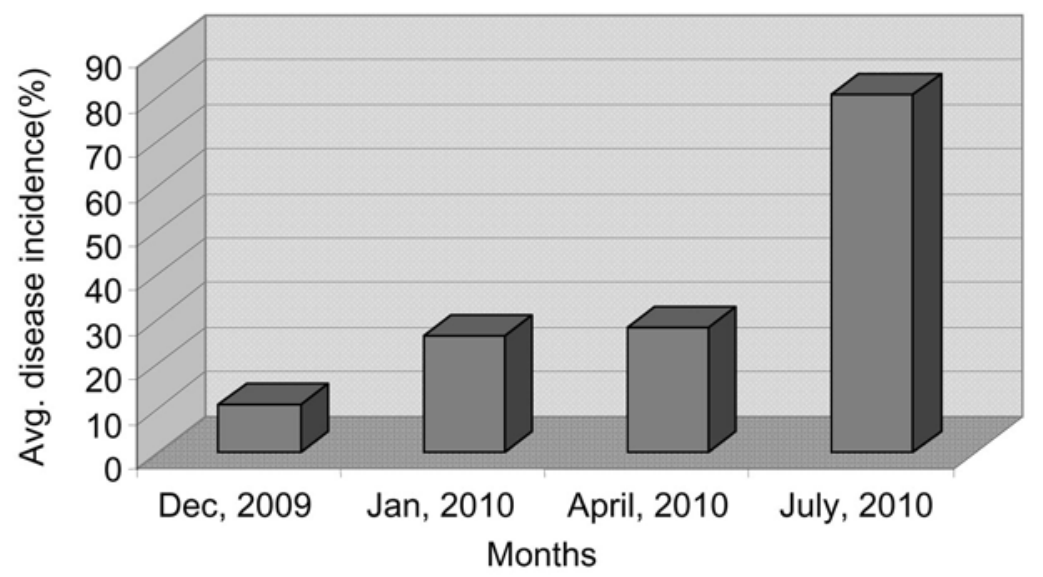

Fig. 1. Anthracnose disease incidence in three selected betel vine fields of Shalon village.

Fig. 1 also shows that, in average, disease incidence was lowest in December (10.87\%) and highest in July (80.50\%). It is well known that in Bangladesh, humidity remains high during the month of July. Huq(6) reported that disease caused by C. capsici on betel vine in Barisal district was high during the month of November to March when atmospheric humidity was less. These differences with the present study might be due to the difference in the pathogenic fungal species.

The fungi associated with the anthracnose infected betel vine and their per cent frequencies are shown in Table 1. Following tissue planting method, a total of 3 fungal isolates were identified from infected stems collected from Shalon and 5 fungal isolates were identified from infected betel stems collected from Mohanpur. Forty seven per cent inocula prepared from the Shalon's sample were found to be associated with Colletotrichum gloeosporioides, whereas, it was $20 \%$ in case of Mohanpur. On the other hand, C. dematium were found associated with $25 \%$ inocula prepared from the Mohanpur's stem only. 
Among the identified fungal isolates, Colletotrichum gloeosporioides is a known causal agent of anthracnose of betel vine(5). In accordance with the present study $C$. dematium was also isolated from betel vine though, its pathogenicity on the vine was not confirmed ${ }^{(24)}$. The occurrence of other fungi including Alternaria sp., Curvularia sp. and Fusarium sp., found associated with anthracnose infected stems might be treated as secondary invaders.

Table 1. Per cent frequency of fungi associated with anthracnose infected betel stems of two different villages.

\begin{tabular}{lcc}
\hline \multirow{2}{*}{ Fungi } & \multicolumn{2}{c}{ Per cent frequency } \\
\cline { 2 - 3 } & Shalon & Mohanpur \\
\hline Alternaria sp. & - & 10 \\
Colletotrichum dematium & - & 25 \\
C. gloeosporioides & 47 & 20 \\
Curvularia sp. & 14 & 04 \\
Fusarium sp. & 33 & 23 \\
Other fungi & 06 & 18 \\
\hline
\end{tabular}

$-=$ Not found

Characteristic brown or deep brown lesions, the symptom of anthracnose disease, were developed when Colletotrichum dematium and C. gloeosporioides were inoculated artificially on the betel stems. The sizes of the lesions were measured about $3.5 \times 1.5-12.0$ $\times 3.0 \mathrm{~mm}^{2}$. The affected portion of plants showed general loss of tissues similar those were also observed in naturally infected plants. In the net house average temperature was recorded $29 \pm 2^{\circ} \mathrm{C}$.

Colletotrichum dematium and C. gloeosporioides were confirmed when fungi were reisolated from the artificially inoculated stems. Their morphological characteristics were also similar to those were inoculated in the tests of pathogenicity. Colletotrichum dematium as causal agent of anthracnose of betel vine is a new document.

Radial growth inhibition ability in vitro of the five systemic fungicides against Colletotrichum dematium and C. gloeosporioides at 50, 100, 200, 300, 400, and 500 ppm concentrations are presented in Table 2. Complete inhibition of growth of the $C$. dematium was observed with corozole, trooper and folicur at 200, 300 and 400 ppm concentrations, respectively. On the other hand, it was achieved with corozole, bavistin, trooper and folicur against $C$. gloeosporioides at 50, 100, 200 and 300 ppm, respectively (Table 2).

In accordance with the present study, Sharma and Verma ${ }^{(11)}$ reported that bavistin checked the growth of Colletotrichum gloeosporioides, causal agent of anthracnose of Mangifera indica L. completely at $100 \mathrm{ppm}$. XU et al.(12) also reported the same trend in 
carbendazim, the active ingredient of bavistin. In contrast with the present study, Bhanumathi and Rai ${ }^{(10)}$ observed that bavistin was most effective in inhibiting the growth of $C$. dematium causing leaf blight of Azadirachta indica. Variations on efficiency of the same fungicide in different studies might be due to the differences of strains of the pathogen. Efficiency gradients observed in the present study expressed that corozole was the best inhibiting agent of the growth of $C$. dematium and C. gloeosporioides, the causal agent of anthracnose of betel vine.

Table 2. Per cent growth inhibition of Colletotrichum dematium and C. gloeosporioides at different concentrations of fungicides.

\begin{tabular}{|c|c|c|c|c|c|c|c|}
\hline \multirow[t]{2}{*}{ Pathogen } & \multirow{2}{*}{$\begin{array}{l}\text { Name of } \\
\text { fungicide }\end{array}$} & \multicolumn{6}{|c|}{$\%$ growth inhibition at different concentrations (ppm) } \\
\hline & & 50 & 100 & 200 & 300 & 400 & 500 \\
\hline \multirow{5}{*}{ C. dematium } & Bavistin & $52.88^{c}$ & $61.09^{b}$ & $63.83^{\mathrm{b}}$ & $65.04^{\mathrm{b}}$ & $65.96^{\mathrm{b}}$ & $68.08^{\mathrm{b}}$ \\
\hline & Corozole & $89.90^{\mathrm{a}}$ & $90.20^{\mathrm{a}}$ & $100.00^{\mathrm{a}}$ & $100.00^{\mathrm{a}}$ & $100.00^{\mathrm{a}}$ & $100.00^{a}$ \\
\hline & Folicur & $65.14^{\mathrm{b}}$ & $75.84^{\mathrm{a}}$ & $83.18^{b}$ & $83.18^{a}$ & $100.00^{a}$ & $100.00^{\mathrm{a}}$ \\
\hline & Fuji-one & $55.05^{\mathrm{b}}$ & $68.63^{b}$ & $70.43^{\mathrm{b}}$ & $76.32^{\mathrm{b}}$ & $82.50^{\mathrm{b}}$ & $85.67^{a}$ \\
\hline & Trooper & $56.23^{\mathrm{b}}$ & $58.05^{\mathrm{b}}$ & $62.61^{b}$ & $100.00^{a}$ & $100.00^{\mathrm{a}}$ & $100.00^{\mathrm{a}}$ \\
\hline \multirow{5}{*}{ C. gloeosporioides } & Bavistin & $75.38^{\mathrm{b}}$ & $100.00^{b}$ & $100.00^{\mathrm{b}}$ & $100.00^{\mathrm{b}}$ & $100.00^{\mathrm{b}}$ & $100.00^{\mathrm{b}}$ \\
\hline & Corozole & $100.00^{\mathrm{a}}$ & $100.00^{a}$ & $100.00^{\mathrm{a}}$ & $100.00^{a}$ & $100.00^{a}$ & $100.00^{a}$ \\
\hline & Folicur & $89.24^{\mathrm{a}}$ & $90.00^{\mathrm{a}}$ & $90.01^{\mathrm{a}}$ & $100.00^{\mathrm{a}}$ & $100.00^{\mathrm{a}}$ & $100.00^{\mathrm{a}}$ \\
\hline & Fuji-one & $34.40^{c}$ & $53.80^{\mathrm{b}}$ & $58.20^{\mathrm{b}}$ & $60.20^{\mathrm{b}}$ & $71.40^{\mathrm{b}}$ & $75.60^{\mathrm{b}}$ \\
\hline & Trooper & $74.62^{\mathrm{b}}$ & $75.38^{\mathrm{b}}$ & $100.00^{\mathrm{b}}$ & $100.00^{\mathrm{b}}$ & $100.00^{\mathrm{b}}$ & $100.00^{\mathrm{b}}$ \\
\hline
\end{tabular}

$\mathrm{a}, \mathrm{b}$ and $\mathrm{c}$ indicate significance at $\mathrm{p}=0.001,0.01$ and 0.05 , respectively.

The result of colony interactions between the test pathogens and soil fungi are presented in Table 3. According to the model of Skidmore and Dickinson ${ }^{(13)}$ the most common type of colony interaction in most of the cases was grade 3. Penicillium sp. only showed grade 4 of colony interaction against both of the test pathogens.

The maximum inhibition of radial growth of Colletotrichum dematium was exhibited by Penicillium sp. (53.33\%) followed by Aspergillus niger (41.66\%) whereas, it was $50 \%$ in case of C. gloeosporioides by A. niger followed by $45.45 \%$ in Penicillium sp. It was in agreement with the findings of Bashar and Rai(14) where Penicillium spp. showed inhibition of radial growth of Fusarium oxysporum f. sp. ciceri.

Highest intermingled zones were observed between $C$. gloeosporioides and A. niger (3.6 $\mathrm{mm}$ ) followed by the same pathogen and T. viride $(3.5 \mathrm{~mm})$. Slight inhibition zones (1.4 and $1.5 \mathrm{~mm}$ ) were noted in case of Penicillium sp. only against both the pathogens (Table 3). The possible explanations for the cause of microbial antagonism have been 
described by Upadhyay and Rai(25). The occurrence of inhibition zone between the soil fungi and the test pathogens could be considered as a result of the production of antibiotics, $\mathrm{pH}$ changes and competition for nutrients. Mechanical obstruction to the

Table 3. Colony interactions among four soil fungi and two test pathogens.

\begin{tabular}{llcccc}
\hline Pathogen & Soil fungi & $\begin{array}{c}\text { Grade* }^{*} \\
\text { Aspergillus flavus }\end{array}$ & $\begin{array}{c}\text { Inhibition of } \\
\text { pathogen } \\
(\%)\end{array}$ & $\begin{array}{c}\text { Intermingled } \\
\text { zone }(\mathrm{mm})\end{array}$ & $\begin{array}{c}\text { Inhibition } \\
\text { zone (mm) }\end{array}$ \\
\hline \multirow{5}{*}{ C. dematium } & 3 & $35.21^{\mathrm{c}}$ & 1.6 & - \\
& A. niger & 3 & $41.66^{\mathrm{c}}$ & 2.1 & - \\
& Penicillium $\mathrm{sp}$. & 4 & $53.33^{\mathrm{c}}$ & - & 1.5 \\
& Trichoderma viride & 3 & 33.33 & 1.8 & - \\
\hline \multirow{5}{*}{ C. gloeosporioides } & Aspergillus flavus & 3 & $34.21^{\mathrm{c}}$ & 2.4 & - \\
& A. niger & 3 & 50.00 & 3.6 & - \\
& Penicillium sp. & 4 & $45.45^{\mathrm{c}}$ & - & 1.4 \\
& Trichoderma viride & 3 & 38.30 & 3.5 & - \\
\hline
\end{tabular}

$\mathrm{c}$ - indicates significance at $\mathrm{p}=0.05 ; "-"=$ Absent. *Grades from 1 (mutually intermingling growth) to 5 (mutual inhibition at a distance), based on Skidmore and Dickinson(13); Grade 3 = Intermingling growth where the fungus under observation has ceased growth and is being overgrown by another fungus and grade $4=$ Slight inhibition with a narrow demarcation line (1 - $2 \mathrm{~mm})$.

growth and hyphal interference may also attribute to the occurrence of inhibition zone between two fungi in dual cultures. The overgrowth was achieved when one fungal species exhibits higher growth rate, higher capacity of antibiotic production and more tolerance capacity against antibiotics produced in comparison to other ones.

\section{Acknowledgement}

The authors are thankful to Professor Dr. Shahidul Alam, Department of Botany, Rajshahi University, Bangladesh for providing anthracnose diseased betel vine samples from Mohanpur, Rajshahi.

\section{References}

1. Islam S (Ed.) 2012. Banglapedia - The National Encyclopedia of Bangladesh. $2^{\text {nd }}$ ed. Vol. 1-10. Asiatic Society of Bangladesh, Dhaka. pp. 500.

2. Chopra RN, SL Nayar and IC Chopra 1956. Glossary of Indian Medicinal Plants. CSIR., New Delhi. pp. 330.

3. Pradhan D, KA Suri, DK Pradhan and P Biswasroy 2013. Golden heart of the nature: Piper betle L. J. Pharmacognosy and Phytochemistry 1 (6): 147 - 167.

4. Dastur JF 1935. Disease of Pan (Piper betle L.) in central provinces. Proc. Indian Acad. Sci., Sec. B. 1(11): 778-815.

5. Shahzad S 2000. Anthracnose of betel vine in Pakistan. Pak. J. Bot. 32(1): 41 - 44. 
6. Huq MI 2011. Studies on the epidemiology of leaf rot and leaf spot diseases of betel vine (Piper betle L.). Bangladesh J. Sci. Ind. Res. 46(4): 519-522.

7. Raut SK and SS Bhattacharya 1999. Pests and diseases of betel vine (Piper betle) and their natural enemies in India. Experimental \& Applied Acarology 23(4): 319-325.

8. Mehrotra RS 2000. Plant Pathology. Tata McGraw Hill Publishing Co., New Delhi. pp. 771.

9. Acharya A and JN Das 1995. Control of anthracnose of betel vine by fungicidal chemicals. Current Agricul. Res. 8(2): 58 - 60.

10. Bhanumathi A and VR Rai 2007. Leaf blight of Azadirachta indica and its management in vitro. African J. Agricul. Res. 2 (10): 538 -543.

11. Sharma A and KS Verma 2007. In vitro cross pathogenicity and management of Colletotrichum gloeosporioides causing anthracnose of mango. Ann. Plant Prot. Sci. 15(1): 186-188.

12. Xu Dagao, Pan Ru-qian, Zheng Zhong and Wang Zhenzhong 2004. Monitoring of the resistance of Colletotrichum gloeosporioides on mango anthracnose to the fungicide carbendazim. J. South China Agricul. Univ. 25(2): 34-36.

13. Skidmore AM and CH Dickinson 1976. Colony interaction and hyphal interference between Septoria nodorum and phylloplane fungi. Trans. Brit. Mycol. Soc. 66: 57-64.

14. Bashar MA and B Rai 1994. Antagonistic potential of root-region microflora of chickpea against Fusarium oxysporum f. sp. ciceri. Bangladesh J. Bot. 23(1): 13-19.

15. Hasan S and QA Ahmed 1963. A study of the anthracnose diseases of Piper betle L. Agric. Pakistan 14: 204-208.

16. Hossain KS, MAT Mia and MA Bashar 2011. Preferred rice varieties, seed source, disease incidence and loss assessment to bakanae disease. J. Agrofor. Environ. 5(2):125-128.

17. Spurr HW (Jr) and RE Welty 1972. Incidence of tobacco leaf microflora in relation to brown spot disease and fungicidal treatment. Phytopathol. 62: 916-920.

18. Barnett HL and BB Hunter 1998. Illustrated Genera of Imperfect Fungi. Fourth edition. APS Press. The American Phytopathological Society. St. Paul, Minnesota 55121, USA. pp.218.

19. Sutton BC 1980. The Coelomycetes: Fungi imperfecti with pycnidia, acervuli and stromata. Commonwealth Mycological Institute, Kew, Surrey, England. pp. 696.

20. Hossain KS and MA Bashar 2011. In vitro effect of plant extracts, fungicides and antibiotics on the fungal isolates associated with damping-off disease of crucifers. J. Agrofor. Environ. 5(2): 17-20.

21. Steel RGD and JH Torrie 1960. Principles and Procedures of Statistics. MacGraw Hill Book Co., New York. pp. 481.

22. Thom C and K Raper 1945. A Manual of the Aspergilli. The Williams \& Wilkins Company, Baltimore. pp. 272.

23. Rifai MA 1969. A Revision of the Genus Trichoderma. Mycological papers no. 116. Commonwealth Mycological Institute, Kew, Surrey, England. pp. 56.

24. Holliday P 1980. Fungus Diseases of Tropical Crops. $1^{\text {st }}$ ed. The press syndicate of the University of Cambridge, USA. pp. 624.

25. Upadhyay RS and B Rai 1987. Studies on antagonism between Fusarium udum Butler and rootregion microflora of pigeon pea. Plant and Soil 101: 79-93. 